\title{
Positive regulation of colonization factor antigen I (CFA/I) production by enterotoxigenic Escherichia coli producing the colonization factors CS5, CS6, CS7, CS17, PCFO9, PCFO159:H4 and PCFO166
}

\author{
Martin L. Hibberd, $\dagger$ Moyra M. McConnell, ${ }^{*}$ Geraldine A. Willshaw, Henry R. Smith \\ and BERNARD ROWE
}

Division of Enteric Pathogens, Central Public Health Laboratory, 61 Colindale Avenue, London NW9 5HT, UK

(Received 24 January; revised 8 April 1991; accepted 29 April 1991)

\begin{abstract}
Enterotoxigenic Escherichia coli (ETEC) strains of nineteen serogroups which produced colonization factors (colisurface-associated antigens CS5, CS6, CS7 and CS17, colonization factor antigen CFA/III and putative colonization factors PCFO159:H4, PCFO166 and PCFO9) were tested for hybridization with a DNA probe containing the $c f a D$ sequence that regulates expression of CFA/I. Strong colony hybridization, similar to that with the CFA/I-positive control strain H10407, occurred with ETEC strains of serogroups O27, O159 and O169 which produced CS6 antigen, and with all the strains which produced PCFO166 fimbriae. Weak colony hybridization, compared to the control strain, was found with ETEC producing CS5 fimbriae with CS6 antigen, CFA/III fimbriae with CS6 antigen, CS7 fimbriae or PCFO159: H4 fimbriae. CS6-antigen-positive strains of serogroups 079, 089 and 0148 and all the CS17-antigen-positive and PCFO9-fimbriae-positive strains were negative in colony hybridization tests with the $c f a D$ probe. Plasmid DNA of nine ETEC strains and their colonization-factor-negative derivatives was tested for hybridization with the $c f a D$ probe and with ST and LT oligonucleotide probes. The sequences that hybridized with the $c f a D$ probe were on the plasmids which coded for enterotoxin production. Fifteen strains were transformed with NTP513, a recombinant plasmid which contains the CFA/I region 1 fimbrial subunit operon but lacks a functional $c f a D$ sequence, in order to determine whether DNA in any of these strains could substitute for the $c f a D$ sequence in the regulation of production of CFA/I fimbriae. Transformants of five strains which produced the colonization factors CS6, PCFO166, CS5 + CS6, CS7 and PCFO9, and of one strain which was a colonization-factor-negative derivative of the CS5,CS6-producing strain E17018, gave good production of CFA/I fimbriae comparable to the CFA/I-positive control strain H10407. Transformants of two strains, producing PCFO159 fimbriae and CS17 antigen, respectively, gave weak CFA/I production. Transformants of one strain producing CS6 antigen and of six colonization-factor-negative derivatives did not produce CFA/I fimbriae. These results showed that plasmids in seven of eight types of colonization-factor-positive strains contained gene sequences which could substitute functionally for the $c f a D$ sequence. Only two of these strains had gene sequences that hybridized strongly with the $c f a D$ probe.
\end{abstract}

\section{Introduction}

Enterotoxigenic Escherichia coli (ETEC) adhere to the mucosa of the small intestine by means of serologically distinct colonization factors and cause disease by releasing enterotoxins, either heat labile (LT), heat stable

† Present address: King's College School of Medicine and Dentistry, Bessemer Road, London SE5 9PJ, UK.

Abbreviations: CFA, colonization factor antigen: CS, coli-surfaceassociated antigen; ETEC, enterotoxigenic Escherichia coli; EIEC, enteroinvasive E.coli; EPEC, enteropathogenic E. coli; LT, heat-labile enterotoxin; MRHA, mannose-resistant haemagglutination; PCF, putative colonization factor; ST, heat-stable enterotoxin.
(ST) or both. A number of colonization factor antigens (CFAs) have now been identified in ETEC of human origin. CFA/I is a single fimbrial antigen (Evans et al., 1975); CFA/II consists of three coli-surface-associated (CS) antigens, CS1, CS2 and CS3 (Evans \& Evans, 1978; Cravioto et al., 1982; Smyth, 1982); CFA/IV is also an antigen complex comprising CS4, CS5 and CS6. Other possible colonization factors are: CFA/III (Honda et al., 1984); putative colonization factor PCFO159:H4 (PCFO159) (Tacket et al., 1987); PCFO166 (McConnell et al., 1989a); PCFO9 (Heuzenroeder et al., 1990); CS17 (McConnell et al., 1990); and the fimbriae of strain 334, termed CS7 (Thorne et al., 1979; Hibberd et al., 1990). 
All of the colonization factors described above require plasmid genes for expression and these are usually associated with enterotoxin-coding genes. A plasmid sequence termed $r n s$ (regulation of $\mathrm{C} \underline{\mathrm{S}} 1$ expression) (Caron et al., 1989) positively regulates the structural genes for CS1 fimbriae which are on a separate plasmid (Willshaw et al., 1990b; Perez-Casal et al., 1990). The rns sequence also regulates the production of CS2 fimbriae; the structural genes for these fimbriae are probably chromosomally located (Caron et al., 1989). In the case of CFA/I fimbriae all the genes for assembly and expression of the fimbriae are located on two regions of a single plasmid that also codes for ST (Smith et al., 1982). These two regions have been cloned separately (Willshaw $e t$ al., 1983). Region 1, present in plasmid NTP513, includes an operon which codes for the fimbrial subunit and other proteins involved in the production of CFA/I fimbriae (Willshaw et al., 1985; Hamers et al., 1989), and region 2 includes a regulatory sequence, $c f a D$, that positively controls expression of CFA/I fimbriae (Savelkoul et al., 1990). The $r n s$ and $c f a D$ sequences are more than $96 \%$ homologous and can substitute for each other functionally (Savelkoul et al., 1990). ETEC strains of serotype O25: $\mathrm{H} 42$ which produce CS4 and CS6 have also been shown to possess sequences that hybridize to the $c f a D$ probe (Willshaw et al., 1990a) or the rns probe (Caron et al., 1990). These sequences are located on a plasmid that also encodes CS6 and that is separate from the plasmid carrying the structural genes for CS4 fimbriae (Willshaw et al., 1990a). Both plasmids are required for CS4 production in the wild-type strain. The cloned $c f a D$ gene can substitute for the CS4 regulatory sequence and promote CS4 expression.

To investigate the distribution of fimbrial regulator genes in ETEC, a group of strains producing different colonization factors has been examined. The strains were tested for hybridization with a $c f a D$ probe, and the presence of functional regulatory elements was determined by measuring the expression of CFA/I fimbriae from an introduced cloned CFA/I fimbrial operon. The production of CFA/I fimbriae was determined by mannose-resistant haemagglutination (MRHA) tests, enzyme-linked immunosorbent assays (ELISAs) and by Western blotting.

\section{Methods}

Bacterial strains and plasmids. Sixty-one ETEC, of nineteen different serogroups, which produced colonization factors, were tested with the $c f a D$ probe by colony hybridization (Table 1). Nine of these colonization-factor-positive ETEC strains, designated A, and the colonization-factor-negative variants, designated $B$, (Table 2) were used for other tests. Strains $\mathrm{H} 10407$ and $\mathrm{H} 10407 \mathrm{P}$ were used as CFA/Ipositive and -negative controls (Table 2). GL497 was an E. coli K12 strain which contained a plasmid, pDEP3-Tc, that had been transferred from a strain of serotype O167:H5. This plasmid coded for CS5 fimbriae, CS6 antigen and ST production (Thomas et al., 1987) and had been marked with tetracycline resistance by transposition ( $L$. Thomas, personal communication). Two enteropathogenic $E$. coli (EPEC) of serogroups $\mathrm{O} 127$ and $\mathrm{O} 128$ and two enteroinvasive $E$. coli (EIEC) of serogroups $\mathrm{O} 28$ and 0143 were also used as recipients in transformation experiments.

Strain 58R80 is $E$. coli $\mathrm{K} 12$ containing the plasmid NTP513 which is a derivative of vector plasmid pACYC184 containing CFA/I region 1 (Willshaw et al., 1983). Plasmid NTP513 also contains sequences that hybridize with $c f a D$, but are not functional in the regulation of CFA/I fimbriae (Gaastra et al., 1990). Strains carrying plasmid NTP513, which codes for chloramphenicol resistance, were grown in the presence of this antibiotic $\left(20 \mu \mathrm{g} \mathrm{ml}^{-1}\right)$ to ensure that it was maintained in the host strains. Plasmid pIVB3-100 (Savelkoul et al., 1990), carrying the subcloned $c f a D$ sequence, was used as the source of the $c f a D$ probe.

Mannose-resistant haemagglutination. Strains were grown overnight on CFA agar containing bile salts (CFAB) (McConnell et al., 1989a) and tested for haemagglutination with bovine red blood cells in the presence of $0.5 \%$ mannose for adhesion fimbriae as previously described (Cravioto et al., 1982).

Plasmid DNA studies. Plasmid DNA was prepared by the method of Birnboim \& Doly (1979) and separated by electrophoresis on $0.6 \%$ agarose gels as previously described (Willshaw et al., 1979). Molecular masses of the plasmids were determined relative to standard plasmids run on the same gel. Purified DNA of plasmid NTP513 was prepared by $\mathrm{CsCl} /$ ethidium bromide density gradient centrifugation (Willshaw et al., 1983) and transformed into $E$. coli strains using the method of Kushner (1978). Transformants were selected on nutrient agar containing chloramphenicol $\left(20 \mu \mathrm{g} \mathrm{ml}^{-1}\right)$.

DNA hybridization. The strains shown in Tables 1 and 2 and described above were spotted onto nylon membranes (Hybond $\mathrm{N}$, Amersham) and prepared for colony hybridization (Maniatis et al., 1982). Plasmid DNA from the strains was separated by gel electrophoresis and blotted onto membranes (Southern, 1975). Gels were not photographed since exposure to ultraviolet radiation resulted in reduced hybridization. Colony filters and blots were hybridized with a DNA probe for the $c f a D$ sequence consisting of a $1.5 \mathrm{kbp} \mathrm{EcoRI-}$ $X b a I$ fragment of pIVB3-100 labelled with deoxyadenosine $S^{\prime}-\alpha-$ $\left[{ }^{35}\right.$ S]thiotriphosphate (Savelkoul et al., 1990). A 0.5 kbp DraI fragment internal to the rns sequence (Caron et al., 1990) was also used in some tests. Hybridization was carried out in $50 \%(\mathrm{v} / \mathrm{v})$ formamide at $37^{\circ} \mathrm{C}$ (Willshaw et al., 1990a). The same blots were stripped of radioactive probe and retested with probes for ST and LT genes. These were alkaline-phosphatase-linked oligonucleotides (SNAP system, DuPontNEN) and were used according to the manufacturer's instructions.

Preparation of antisera and antigens. Antisera to antigens CFA/I, CS5, CS6, CS7, CS17, CFA/III, PCFO9, PCFO159 and PCFO166 were prepared by making peptone-water suspensions from overnight cultures grown on slopes of CFAB of a well-characterized strain expressing one or two of these antigens. Suspensions were formalinized and used to immunize rabbits (Cravioto et al., 1982). Each antiserum was then absorbed with an adhesin-negative variant of the immunizing strain to make it specific for the adhesin (Cravioto et al., 1982; McConnell \& Rowe, 1989; McConnell et al., 1988a, 1990; Hibberd et al., 1990). Bacteria were grown at $37^{\circ} \mathrm{C}$ overnight on CFAB or CFAB with chloramphenicol $\left(20 \mu \mathrm{g} \mathrm{ml}^{-1}\right)$ when the strains contained plasmid NTP513. For ELISAs bacteria were resuspended from CFAB slopes into $2 \mathrm{ml} 0.05 \mathrm{M}$-sodium carbonate/bicarbonate buffer $(\mathrm{pH} \mathrm{9.6)}$ and for SDS-PAGE bacteria were scraped from $150 \mathrm{~mm}$ CFAB plates into $1.5 \mathrm{ml}$ of saline $(0.85 \% \mathrm{NaCl})$. Both suspensions were heated at $60^{\circ} \mathrm{C}$ 
Table 1. Colony hybridization with a cfaD probe of ETEC strains producing different colonization factors

\begin{tabular}{|c|c|c|c|c|c|}
\hline $\begin{array}{l}\text { Colonization } \\
\text { factor } \\
\text { antigen }\end{array}$ & $\begin{array}{l}\text { Entero- } \\
\text { toxin }\end{array}$ & $\begin{array}{l}\text { Total } \\
\text { no. of } \\
\text { strains }\end{array}$ & Serogroup $*$ & $\begin{array}{c}\text { Colony } \\
\text { hybridization } \\
\text { with } c f a D \\
\text { probe† }\end{array}$ & Reference \\
\hline $\mathrm{CS} 5, \mathrm{CS} 6$ & ST & 7 & $\mathrm{O} 29(1), \mathrm{O} 114(2), \mathrm{O} 115(2), \mathrm{O} 167(2)$ & W & Hibberd et al. (1990) \\
\hline CS6 & ST & 10 & $\mathrm{O} 27(4), \mathrm{O} 159(4), \mathrm{O} 169(2)$ & $\mathbf{S}$ & Hibberd et al. (1990) \\
\hline CS6 & $\begin{array}{l}\text { ST or } \\
\text { ST + LT }\end{array}$ & 6 & $\mathrm{O} 79(1), 089(1), 0148(4)$ & - & Hibberd et al. (1990) \\
\hline CFA/III,CS6 & LT & 5 & $025(5)$ & W & McConnell et al. (1989a) \\
\hline PCFO159 & $\mathrm{ST}+\mathrm{LT}$ & 4 & $0159(4)$ & W & McConnell et al. (1989a) \\
\hline PCFO166 & $\begin{array}{l}\text { ST or } \\
\text { ST }+ \text { LT }\end{array}$ & 10 & $\mathrm{O} 20(4), \mathrm{O} 78(1), \mathrm{O} 98(2), \mathrm{O} 166(3)$ & $\mathrm{S}$ & $\begin{array}{l}\text { McConnell et al. (1989a), } \\
(1991)\end{array}$ \\
\hline $\mathrm{CS} 17$ & LT & 9 & $\mathrm{O} 8(3), \mathrm{O} 15(2), \mathrm{O} 48(1), \mathrm{O} 114(2), \mathrm{O} 146(1)$ & - & McConnell et al. (1990) \\
\hline CS7 & $\begin{array}{l}\mathrm{LT} \text { or } \\
\mathrm{ST}+\mathrm{LT}\end{array}$ & 8 & $\mathrm{O} 15(3), 0103(1), 0114(4)$ & W & $\begin{array}{l}\text { Hibberd et al. (1990), } \\
\text { McConnell et al. (1991) }\end{array}$ \\
\hline PCFO9 & LT & 2 & $\mathrm{O9}(2)$ & - & Hibberd et al. (1990) \\
\hline
\end{tabular}

* Numbers of strains of each serogroup tested are given in parentheses.

$+\mathrm{W}$, Weak hybridization compared to that with the CFA/I-positive control strain H10407; S, strong hybridization similar to that with the CFA/I-positive control strain H10407.

for $30 \mathrm{~min}$. The heat-released extracts for SDS-PAGE were then centrifuged for $2 \mathrm{~min}$ at 5000 r.p.m. and these supernatants and the ELISA suspensions were stored at below $-10^{\circ} \mathrm{C}$.

ELISAs. Heated suspensions of strains grown on CFAB or CFAB with chloramphenicol $\left(20 \mu \mathrm{g} \mathrm{ml}^{-1}\right)$ were used to coat wells in microtitre plates, and antigens were detected using specific antisera as previously described (McConnell \& Rowe, 1989). At least three suspensions of each transformant prepared from separate CFAB slopes were tested and found to give consistent results.

SDS-PAGE and immunoblotting. Fimbrial subunits were separated by SDS-PAGE by the method of Laemmli (1970) using vertical slab gels. Extracts were run on $20 \%(\mathrm{w} / \mathrm{v})$ polyacrylamide gels for $3.5 \mathrm{~h}$ at $50 \mathrm{~mA}$. Proteins of known molecular mass were run on the same gel. Western blotting was performed by transferring the proteins separated by SDS-PAGE onto nitrocellulose membranes $(0.35 \mathrm{~A}, 2 \mathrm{~h})$ as described by Towbin et al. (1979). After washing, the bound antibodies were detected with goat anti-rabbit IgG conjugated to alkaline phosphatase (Hibberd et al., 1990). Standard volumes of the heatreleased extracts were run on SDS-PAGE. At least three separate preparations of each extract were tested.

\section{Results and Discussion}

\section{Identification of strains hybridizing with a cfaD probe}

The results of colony hybridization tests with the $c f a D$ probe on the ETEC strains producing different colonization factors are shown in Table 1. Ten strains of serogroups $\mathrm{O} 27, \mathrm{O} 159$ and $\mathrm{O} 169$ that produced CS6 antigen and all the ten strains producing PCFO166 fimbriae gave a strong hybridization signal which was similar to that with the CFA/I-positive control strain H10407 suggesting that these strains contained a regulatory sequence similar to $c f a D$. Strains producing CS5 fimbriae with CS6 antigen, CFA/III fimbriae with
CS6 antigen, PCFO159 fimbriae or CS7 fimbriae showed weak hybridization with the $c f a D$ probe that was, however, reproducible and clearly distinguishable from the negative control strain, H10407P. Strains producing CS17 fimbriae, PCFO9 fimbriae and six strains of serogroups O79, O89 and O148 which produced CS6 antigen did not hybridize with the $c f a D$ probe. Our results suggested that CS6 antigen-positive strains of certain serogroups have a DNA regulatory sequence similar to $c f a D$; this sequence was not present in CS6-antigen-positive strains of other serogroups. Caron et al. (1990) have recently reported that 10 of 27 ETEC that produced CS6 antigen without CS4 or CS5 fimbriae hybridized with their $r n s$ probe. The serogroups of their strains were not reported.

The results of colony hybridization tests with the $c f a D$ probe, for nine representative colonization-factor-positive strains, the CFA/I-positive control strain $\mathrm{H} 10407$ and the colonization-factor-negative derivatives of these ETEC are shown in Table 2. The results for the colonization-factor-positive strains were as described above. The colonization-factor-negative derivatives did not hybridize with the $c f a D$ probe, except for the CS5, CS6-negative variant, E17018B, which gave a weak hybridization reaction like the CS5,CS6-producing strain, E17018A, to which it is related. Strain GL497, the E. coli $\mathrm{K} 12$ strain which carried plasmid pDEP3-Tc coding for CS5 fimbriae and CS6 antigen also gave a weak reaction with the $c f a D$ probe.

Blotted plasmid DNA preparations from the strains in Table 2 were tested for hybridization, first with the $c f a D$ probe, then with oligonucleotide probes for ST and LT genes (Fig. 1). In strain E7476A (O166:H27), which 
Table 2. Hybridization with probes for cfaD and enterotoxin genes of representative ETEC strains producing different colonization factors

\begin{tabular}{|c|c|c|c|c|c|c|c|c|c|}
\hline \multirow[b]{2}{*}{ Strain } & \multirow[b]{2}{*}{ Serotype } & \multirow{2}{*}{$\begin{array}{c}\text { Entero- } \\
\text { toxin }\end{array}$} & \multirow{2}{*}{$\begin{array}{l}\text { Colonization } \\
\text { factor } \\
\text { produced }\end{array}$} & \multirow{2}{*}{$\begin{array}{l}\text { MRHA of } \\
\text { bovine } \\
\text { erythrocytes }\end{array}$} & \multirow{2}{*}{$\begin{array}{c}\text { Colony } \\
\text { hybridization } \\
\text { with } c f a D \\
\text { probe* }\end{array}$} & \multicolumn{3}{|c|}{$\begin{array}{c}\text { Molecular size (MDa) } \\
\text { of plasmid band } \\
\text { hybridizing with } \\
\text { probe for: }\end{array}$} & \multirow[b]{2}{*}{ Reference } \\
\hline & & & & & & $c f a D$ & ST & LT & \\
\hline E17018A & $\mathrm{O} 167: \mathrm{H} 5$ & ST & CS5,CS6 & + & W & 78 & 78 & - & Thomas et al. (1985) \\
\hline E17018B & O167:H5 & - & - & - & W & $66 \dagger$ & - & - & Thomas et al. (1985) \\
\hline E3135A & $\mathbf{O} 27: \mathbf{H 7}$ & ST & CS6 & - & $\mathbf{S}$ & 90 & 90 & - & McConnell et al. (1988) \\
\hline E3135B & $\mathbf{O} 27: \mathbf{H} 7$ & - & - & - & - & - & - & - & McConnell et al. (1988) \\
\hline E519/66A & $\mathrm{O} 148: \mathrm{H} 28$ & ST & CS6 & - & - & - & 50 & - & McConnell et al. (1988) \\
\hline E519/66B & $\mathrm{O} 148: \mathrm{H} 28$ & - & - & - & - & - & - & - & McConnell et al. (1988) \\
\hline $31-10 \mathrm{~A}$ & $025: \mathrm{H}^{-}$ & LT & CFA/III,CS6 & - & W & 60 & - & 60 & McConnell \& Rowe (1989) \\
\hline $31-10 \mathrm{~B}$ & $\mathrm{O} 25: \mathrm{H}^{-}$ & - & - & - & - & - & - & - & McConnell \& Rowe (1989) \\
\hline $350 \mathrm{ClA}$ & $\mathrm{O} 159: \mathrm{H} 4$ & ST,LT & PCFO159 & - & W & 30 & 30 & 30 & McConnell \& Rowe (1989) \\
\hline $350 \mathrm{C} 1 \mathrm{~B}$ & $\mathrm{O} 159: \mathrm{H} 4$ & - & - & - & - & - & - & - & McConnell \& Rowe (1989) \\
\hline E7476A & $\mathrm{O} 166: \mathrm{H} 27$ & ST & PCFO166 & + & $\mathbf{S}$ & 100 & 100 & - & McConnell et al. (1989a) \\
\hline E7476B & $\mathrm{O} 166: \mathrm{H} 27$ & - & - & - & - & - & - & - & McConnell et al. $(1989 a)$ \\
\hline E20738A & $\mathrm{O} 114: \mathrm{H} 21$ & LT & $\mathrm{CS} 17$ & + & - & - & - & 100 & McConnell et al. (1990) \\
\hline E20738B & $\mathrm{O} 114: \mathrm{H} 21$ & - & - & - & - & - & - & - & McConnell et al. (1990) \\
\hline E29101A & $\mathrm{O} 114: \mathrm{H} 49$ & LT & CS7 & + & $\mathbf{W}$ & 63 & - & 63 & Hibberd et al. (1990) \\
\hline E29101B & $\mathrm{O} 114: \mathrm{H} 49$ & - & - & - & - & - & - & - & Hibberd et al. (1990) \\
\hline PE360A & $\mathrm{O} 9: \mathrm{H}^{-}$ & LT & PCFO9 & - & - & - & - & 75 & Heuzenroeder et al. (1990) \\
\hline PE360B & $\mathrm{O} 9: \mathrm{H}^{-}$ & - & - & - & - & - & - & - & Unpublished \\
\hline H10407 & O78:H11 & ST,LT & CFA/I & + & $\mathbf{S}$ & 60 & $60,42 \ddagger$ & 42 & Evans et al. (1975) \\
\hline H10407P & $\mathrm{O} 78: \mathrm{H} 11$ & LT & - & - & - & - & 42 & 42 & Evans et al. (1975) \\
\hline
\end{tabular}

* W, Weak hybridization compared to that with the CFA/l-positive control strain H10407; S, strong hybridization similar to that with the CFA/I-positive control strain H10407.

† This plasmid was probably derived from the $78 \mathrm{MDa}$ plasmid in strain E17018A by deletion.

$\ddagger$ The ST genes encoded by this $42 \mathrm{MDa}$ plasmid are not functional (Smith et al., 1985).

gave a strong colony hybridization reaction with the $c f a D$ probe, the plasmid which coded for ST and PCFO166 fimbriae hybridized strongly with the $c f a D$ probe. PCFO166 fimbriae are similar in morphology to CFA/I, CS1, CS2 and CS4 fimbriae (McConnell et al., 1989a); however, although the subunits of CFA/I, CS1, CS2 and CS4 fimbriae are antigenically related to each other, they are not related to the subunits of PCFO166 fimbriae (McConnell et al., 1989b). In strain E3135A (serotype $\mathrm{O} 27: \mathrm{H} 7$ ), which also gave a strong colony hybridization reaction with the $c f a D$ probe, the plasmid coding for $S T$, CS6 antigen and $2 \mathrm{~nm}$ diameter fibrils (Knutton et al., 1989) hybridized with the $c f a D$ probe. The hybridizations in the region of the residual chromosomal DNA in the plasmid DNA preparations from strains E3135A, E7476A and the control strain H10407 (Fig. 1) were probably due to linearized plasmid DNA. Linear DNA of large plasmids migrates in the same position as chromosomal DNA (Willshaw et al., 1979). Strains that gave weak reactions in colony hybridization with the $c f a D$ probe also possessed plasmids which gave weak reactions in the Southern hybridization with the $c f a D$ probe (Fig. 1), and these plasmids also hybridized with enterotoxin oligonucleotide probes. Strain E17018A (serotype O167:H5) contained a 78 MDa plasmid which coded for CS5 fimbriae, CS6 antigen and ST (Thomas et $a l ., 1985)$ and hybridized weakly with the $c f a D$ probe (Fig. 1). Strain E17018B, which did not produce CS5 fimbriae, CS6 antigen or ST, contained a $66 \mathrm{MDa}$ plasmid which was not present in the original strain; this plasmid hybridized with the $c f a D$ probe but not with the ST probe. It was presumably derived from the $78 \mathrm{MDa}$ plasmid of strain E17018A by deletion of DNA sequences, with concomitant loss of the ability to code for CS5 fimbriae, CS6 antigen and ST. None of the plasmids in the other colonization-factor-negative strains hybridized with the $c f a D$ probe (Table 2). The chromosomal DNA of the colonization-factor-negative variants E3135B, E7476B (results not shown) and H10407P (Fig. 1) did not hybridize with the $c f a D$ probe. This confirms that hybridization of chromosomal DNA of E3135A, E7476A and $\mathrm{H} 10407$ was due to linear plasmid DNA and not to the presence of sequences homologous with $c f a D$ in the chromosome.

Since the fragment used as a $c f a D$ probe contained DNA flanking the $c f a D$ gene, some hybridizations were repeated using a probe internal to the rns gene. The $r n s$ and $c f a D$ genes are $96 \%$ homologous (Savelkoul et al., 


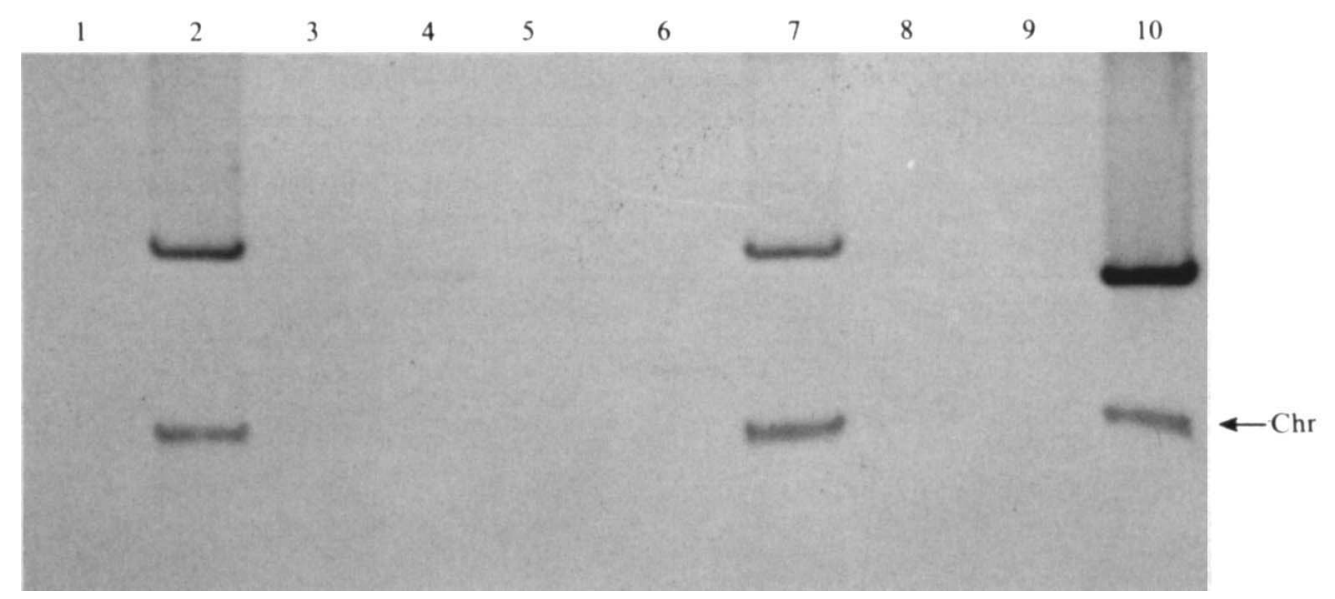

Fig. 1. Hybridization of the $c f a D$ probe to blotted plasmid DNA preparations from the colonization-factor-producing strains described in Table 1. The plasmid DNA was separated on a $0.6 \%(\mathrm{w} / \mathrm{v})$ agarose gel, blotted to nylon membrane and hybridized with the $c f a D$ probe. Probe labelling and hybridization were as described in Methods. The presence of hybridizing bands was detected by autoradiography. Plasmid DNA was from E. coli strains (own colonization factor in parentheses) as follows: lane 1, PE360A (PCFO9); lane 2, E3135A (CS6); lane 3, E20738A (CS17); lane 4, E29101 A (CS7); lane 5, E519/66A (CS6); lane 6, 350C1A (PCFO159); lane 7, E7476A (PCFO166); lane 8, E17018A (CS5, CS6); lane 9, H10407P; lane 10, H10407 (CFA/I). Chr marks the position at which chromosomal and linear plasmid DNA migrated on the gel (Willshaw et al., 1979).

1990). The $r n s$ probe was a $0.5 \mathrm{kbp}$ DraI fragment described in Caron et al. (1990) which was internal to the $r n s$ gene and, by analogy, the $c f a D$ gene. No differences were found between the results with the two probes (not shown), indicating that hybridization observed with the $c f a D$ probe was unlikely to be due to flanking DNA. The conditions for hybridization (Willshaw et al., 1990b) were based on the reported low $\mathrm{mol} \% \mathrm{G}+\mathrm{C}$ value of the $c f a D$ gene (Savelkoul et al., 1990). Increasing the temperature of hybridization to $42{ }^{\circ} \mathrm{C}$ in $50 \%$ formamide and stringent washing conditions (Maniatis et al., 1982) resulted in loss of the weak signals in colony hybridizations and reduction in the positive control hybridization.

\section{Analysis of strains for the presence of functional regulators}

To investigate whether non-CFA/I and non-CFA/IIpositive ETEC strains carried functional regulatory sequences for CFA/I biogenesis, transformation of nine ETEC strains and the colonization-factor-negative variants (Table 2) with plasmid NTP513 that contained CFA/I region 1 was attempted. Three strains, 31-10A, 31-10B and E20738B, could not be transformed with plasmid NTP513 after three attempts. Ten transformants of each of the other fifteen strains were tested for MRHA with bovine erythrocytes. Four strains, E17018A, E7476A, E20738A and E29101A, gave MRHA due to their own colonization factors. Four other colonization-factor-positive strains, E3135A, 350C1A,
E519/66A and PE306A, were originally MRHA-negative. When transformants of these strains were tested, MRHA was now detected with transformants of three strains, E3135A, 350C1A and PE360A, which could be due to the production of CFA/I fimbriae (Table 3). The transformants of all the colonization-factor-negative variants were MRHA-negative except for the transformants of strain E17018B which were also MRHApositive (Table 3).

Five colonies of the fifteen transformed recipients were tested in ELISAs with CFA/I antiserum. Reproducible results were obtained from repeat experiments so representative results from one experiment are given in Table 3. The transformants of six strains, E3135A, E7476A, E17018A, E17018B, E29101A and PE306A, gave high ELISA readings, showing that CFA/I fimbriae were produced in these strains at a similar level to that in the control strain H10407. Transformants of two strains, $350 \mathrm{C} 1 \mathrm{~A}$ and E20738A, gave positive ELISA readings which were less than half the control value suggesting lower levels of CFA/I production. The transformants of strain E519/66A were ELISA-negative; these transformants did not produce CFA/I fimbriae. Negative ELISA results were obtained with all the colonization-factor-negative transformants except with strain E17018B (Table 3), showing that these strains did not produce CFA/I fimbriae. All the transformants were checked by ELISA for the production of colonization factor antigens that were native to the host strains. They were found to be positive for the antigen as appropriate.

To confirm these MRHA and ELISA results, one transformant of each of the fifteen types was examined 
Table 3. Transformation of ETEC strains with plasmid NTP513 encoding the CFA/I region 1 fimbrial subunit operon to demonstrate the presence of sequences regulating $C F A / I$ expression

\begin{tabular}{|c|c|c|c|c|c|}
\hline \multirow{2}{*}{$\begin{array}{l}\text { Recipient } \\
\text { strain no. }\end{array}$} & \multirow{2}{*}{$\begin{array}{l}\text { Colonization } \\
\text { factor }\end{array}$} & \multirow{2}{*}{$\begin{array}{l}\text { Hybridization } \\
\text { of recipient } \\
\text { strain with } \\
c f a D^{*}\end{array}$} & \multicolumn{3}{|c|}{ Production of $\mathrm{CFA} / \mathrm{I}$ by transformants } \\
\hline & & & MRHA & ELISA $\ddagger$ & Immunoblot $\S$ \\
\hline E3135A & CS6 & $\mathbf{S}$ & + & $1 \cdot 161$ & +++ \\
\hline E3135B & - & - & - & 0.000 & - \\
\hline E7476A & PCFO166 & $S$ & $+t$ & $1 \cdot 112$ & $++t$ \\
\hline E7476B & - & - & - & 0.027 & - \\
\hline E17018A & CS5,CS6 & W & $+\dagger$ & 0.804 & $++t$ \\
\hline $\mathrm{E} 17018 \mathrm{~B}$ & - & W & + & 1.042 & +++ \\
\hline $350 \mathrm{ClA}$ & PCFO159 & W & + & $0 \cdot 297$ & ++ \\
\hline $350 \mathrm{ClB}$ & - & - & - & 0.000 & - \\
\hline E29101A & $\mathrm{CS} 7$ & W & $+\dagger$ & 0.838 & ++ \\
\hline E29101B & - & - & - & 0.038 & - \\
\hline E519/66A & CS6 & - & - & 0.009 & - \\
\hline E519/66B & - & - & - & 0.000 & - \\
\hline E20738A & $\operatorname{CS} 17$ & - & $+t$ & 0.462 & + \\
\hline PE360A & PCFO9 & - & + & 0.824 & ++ \\
\hline PE360B & - & - & - & 0.000 & - \\
\hline
\end{tabular}

* W, Weak hybridization compared to that with the CFA/I-positive control strain H10407; S, strong hybridization similar to that with the CFA/I-positive control strain H10407.

† The MRHA of bovine erythrocytes caused by these strains is partly due to production of the colonization factor native to the recipient strain.

¥ Absorbance at $490 \mathrm{~nm}$ of heated suspensions of cells $\left(10^{10}\right.$ c.f.u. $\left.\mathrm{ml}^{-1}\right)$ compared to a sodium carbonate/bicarbonate buffer blank. At least three suspensions of each transformant prepared from separate CFAB slopes were tested and the results for one transformant of each strain from a representative experiment are given here. The control values were: H10407, 1.035; H10407P, 0.025.

$\S$ Standard volumes of heat-released extracts were run on SDS-PAGE and immunoblotted. At least three separate preparations of each transformant were tested. +++ to + , Intensity of CFA/I subunit band detected; the value for $\mathrm{H} 10407$ was +++ .

by SDS-PAGE and immunoblotting. Analysis of heatreleased extracts of the transformants of strains E3135A, E7476A. E17018A, E17018B, E29101A and PE360A by SDS-PAGE showed prominent bands of molecular mass about $14.4 \mathrm{kDa}$ (Table 3). These bands were similar in molecular mass to the CFA/I subunit band of the control strain H10407. The $14.4 \mathrm{kDa}$ polypeptides were confirmed as the CFA/I subunits by immunoblotting using anti-CFA/I serum (Fig. 2). Standard volumes of crude fimbrial extracts were used for these immunoblots. The intensity of the CFA/I subunit band varied, suggesting that the amount of CFA/I fimbriae produced by the transformants varied (Fig. 2). Transformants of strains E3135A, E7476A, E17018A and E17018B consistently gave the most intense bands which were similar in intensity to that of the CFA/I-positive control strain H10407. Heat-released extracts from transformants of strains 350C1A, E29101A, E20738A and PE360A consistently gave weak reactions with anti-CFA/I serum (Fig. 2). There was no production of CFA/I fimbriae by transformants of strains E519/66A, E3135B, E7476B, 350C1B, E29101B, E519/66B and PE360B (Table 3).
These results showed that, apart from strain E519/66A, all the ETEC strains that contained a plasmid which coded for a colonization factor appeared to regulate positively the production of CFA/I fimbriae, although there was a quantitative difference in the amount CFA/I fimbriae produced. The transformants of all the colonization-factor-negative strains, except strain E17018B which contained a deleted CS5-CS6-ST plasmid, did not produce CFA/I fimbriae. The amount of CFA/I produced by a transformant was not related to the degree of hybridization of the host strain with the $c f a D$ probe. Transformants of host strains which hybridized strongly (E3135A, E7476A), weakly (E17018A, E17018B, E29101A) and not at all (PE360A) produced roughly equal amounts of CFA/I fimbriae, similar to that produced by the CFA/I-positive control strain H10407.

Ten colonies of each EPEC and EIEC strain that had been transformed with NTP513 were MRHA-negative. ELISAs confirmed that the transformants did not produce CFA/I fimbriae. EPEC and EIEC strains contain plasmids which code for factors required for pathogenicity (Baldini et al., 1983; Hale et al., 1983) but 


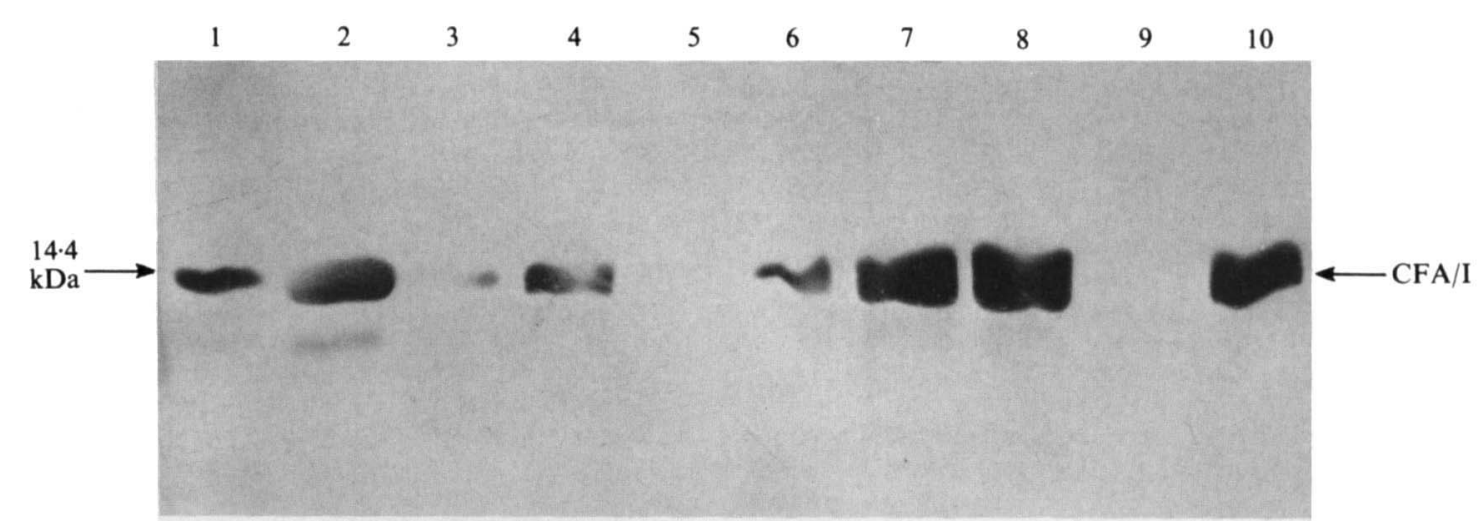

Fig. 2. Expression of the CFA/I fimbrial polypeptide by strains of $E$. coli carrying NTP513, a recombinant plasmid containing the CFA/I region 1 fimbrial subunit operon but lacking a functional $c f a D$ sequence. Saline suspensions of bacteria from CFAB plates were heated at $60^{\circ} \mathrm{C}$ for $30 \mathrm{~min}$, then centrifuged. Samples of the heat-released extracts $(30 \mu \mathrm{l}$ per lane) were separated by $20 \%(\mathrm{w} / \mathrm{v}$, acrylamide) SDS-PAGE for 3-5 h at 50 mA and lanes 1-10 were blotted to nitrocellulose and the presence of CFA/I subunits detected immunologically as described in Methods. The preparations on the gel were made from transformants of the following $E$. coli strains carrying NTP513 (own colonization factor in parentheses). Lane 1, PE360A (PCFO9); lane 2, E3135A (CS6); lane 3, E20728A (CS17); lane 4, E29101A (CS7); lane 5, E519/66A (CS6); lane 6, 350C1A (PCFO159); lane 7, E7476A (PCFO166); lane 8, E1 7018A (CS5, CS6); lane 9, 58R80 (E. coli K12 carrying NTP513); lane 10, H10407 (CFA/I). Arrows indicate the position and size of the fimbrial polypeptide.

the experiments described here show that these plasmids do not have regulatory sequences which positively affect production of CFA/I fimbriae. In this property they differ from the plasmids coding for virulence in ETEC. The majority of these plasmids have a DNA sequence which positively regulates expression of CFA/I fimbriae. Where the plasmids have DNA sequences which hybridize strongly with the $c f a D$ probe, it is likely that these are the sequences which regulate production of CFA/I fimbriae. Whether or not these DNA sequences have any function in regulating the production of the fimbriae indigenous to the strains is not known. In the case of plasmids with DNA sequences that hybridize weakly with the $c f a D$ probe, it is not known if these sequences regulate expression of CFA/I fimbriae. Cloning experiments are required to identify all these regulatory sequences including those of strains E20738A and PE360A which did not hybridize with the $c f a D$ probe.

This work was supported by a grant from the Diarrhoeal Diseases Control Progamme of the World Health Organization.

\section{References}

Baldini, M. M., KaPer, J. B., Levine, M. M., Candy, D. C. A. \& Moon, H. W. (1983). Plasmid-mediated adhesion in enteropathogenic Escherichia coli. Journal of Pediatric Gastroenterology and Nutrition 2, 534-538.

BIRnboim, H. C. \& Doly, J. (1979). A rapid alkaline extraction procedure for screening recombinant plasmid DNA. Nucleic Acids Research 7, 1513-1523.
CARon, J., Coffield L. M. \& ScotT, J. R. (1989). A plasmid-encoded regulatory gene, $r n s$ required for expression of CS1 and CS2 adhesins of enterotoxigenic Escherichia coli. Proceedings of the National Academy of Sciences of the United States of America 86, 963-967.

Caron, J., Maneval, D. R., Kaper, J. B. \& Scott, J. R. (1990). Association of rns homologs with colonization factor antigens in clinical Escherichia coli isolates. Infection and Immunity 58, 34423444.

Cravioto, A., Scotland, S. M. \& Rowe, B. (1982). Hemagglutination activity and colonization factor antigens I and II in enterotoxigenic and non-enterotoxigenic strains of Escherichia coli isolated from humans. Infection and Immunity 36, 189-197.

Evans, D. G. \& Evans, D. J., JR (1978). New surface-associated heatlabile colonization factor antigen (CFA/II) produced by enterotoxigenic Escherichia coli of serogroups O6 and O8. Infection and Immunity 21, 638-647.

Evans, D. G., Silver, R. P., Evans, D. J., Chase, D. G. \& Gorbach, S. L. (1975). Plasmid-controlled colonization factor associated with virulence in Escherichia coli enterotoxigenic for humans. Infection and Immunity 12, 656-667.

Gaastra, W., Jordi, B. J. A. M., Mul, E. M. A., Hamers, A. M., McConnell, M. M., Willshaw, G. A., Smith, H. R. \& Van Der ZEIJST, B. A. M. (1990). A silent regulatory gene $c f a D$ on region 1 of the CFA/I plasmid NTP113 of enterotoxigenic Escherichia coli. Microbial Pathogenesis 9, 285-291.

Hale, T. L., Sansonetti, P. J., Schad, P. A., Austin, S. \& Formal, S. B. (1983). Characterization of virulence plasmids and plasmidassociated outer membrane proteins in Shigella flexneri, Shigella sonnei and Escherichia coli. Infection and Immunity 40, 340-350.

hamers, A. M., Pel, H. J., Willshaw, G. A., Kusters, J. G., Van Der Zeisst, B. A. M. \& GaAstra, W. (1989). The nucleotide sequence of the first two genes of the CFA/I fimbrial operon of human enterotoxigenic Escherichia coli. Microbial Pathogenesis 6, 297-309.

Heuzenroeder, M. W., Elliot, T. R., Thomas, C. J., Halter, R. \& Manning, P. A. (1990). A new fimbrial type (PCFO9) on enterotoxigenic Escherichia coli $\mathrm{O} 9: \mathrm{H}^{-} \mathrm{LT}^{+}$isolated from a case of infant diarrhea in Central Australia. FEMS Microbiology Letters 66, 55-60.

Hibberd, M. L., McConnell, M. M., Field, A. M. \& Rowe, B. (1990). The fimbriae of human enterotoxigenic Escherichia coli strain 
334 are related to CS5 fimbriae. Journal of General Microbiology 136, 2449-2456.

Honda. T., Arita, M. \& Miwatani, T. (1984). Characterization of new hydrophobic pili of human enterotoxigenic Escherichia coli: a possible new colonization factor. Infection and Immunity 43, 959-965.

K nutton, S., McConnell, M. M., Rowe, B. \& MCNeish, A. S. (1989). Adhesion and ultrastructural properties of human enterotoxigenic Escherichia coli producing CFA/III and CFA/IV. Infection and Immunity 57, 3364-3371.

KUSHNER, S. R. (1978). An improved method for transformation of Escherichia coli with ColE1 derived plasmids. In Genetic Engineering, pp. 17-23. Edited by H. W. Boyer \& S. Nicosia. Amsterdam: Elsevier/North Holland Biomedical Press.

LAEMMLI, U. K. (1970). Cleavage of structural proteins during the assembly of the head of bacteriophage T4. Nature, London 227, 680 685

McConnell, M. M. \& Rowe, B. (1989). Prevalence of the putative colonization factors CFA/III and PCFO159:H4 in enterotoxigenic Escherichia coli. Journal of Infectious Diseases 159, 582-586.

McConnell, M. M., Thomas, L. V., Willshaw, G. A., Smith, H. R. \& RowE, B. (1988). Genetic control and properties of coli surface antigens of colonization factor antigen IV (PCF8775) of enterotoxigenic Escherichia coli. Infection and Immunity 56, 1974-1980.

MCConnell, M. M. Chart, H., Field, A. M., Hibberd, M. \& Rowe, B. $(1989 a)$. Characterization of a putative colonization factor (PCFO166) of enterotoxigenic Escherichia coli of serogroup Ol66. Journal of General Microbiology 135, 1135-1144.

MCCONnell, M. M., Chart, H. \& Rowe, B. (1989b). Antigenic homology within human enterotoxigenic Escherichia coli fimbrial colonization factor antigens: CFA/I, coli-surface-associated antigens (CS)1, CS2, CS4 and CS17. FEMS Microbiology Letters 61, 105108

McConnell, M. M., Hibberd, M., Field, A. M., Chart, H. \& Rowe, B. (1990). Characterization of a new putative colonization factor (CS17) from a human enterotoxigenic Escherichia coli of serotype $\mathrm{O} 114: \mathrm{H} 21$ which produces only heat-labile enterotoxin. Journal of Infectious Diseases 161, 343-347.

McConnell, M. M., Hibberd, M. L., Penny, M. E., SCotland, S. M., ChEASTY, T. \& Rowe, B. (1991). Surveys of human enterotoxigenic Escherichia coli from three different geographical areas for possible colonization factors. Epidemiology and Infection (in the Press).

Maniatis. T., Fritsch, E. F. \& SAmbrook, J. (1982). Molecular Cloning: a Laboratory Manual. Cold Spring Harbor, NY: Cold Spring Harbor Laboratory.

Perez-Casal, J., Swartley, J. S. \& Scott, J. R. (1990). Gene encoding the major subunit of CS1 pili of human enterotoxigenic Escherichia coli. Infection and Immunity 58, 3594-3600.

Savelkoul, P. H. M., Willshaw, G. A., McConnell, M. M., Smith, H. R., Hamers, A. J., Van Der Zeisst, B. A. M. \& GaAstra, W. (1990). Expression of CFA/I fimbriae is positively regulated. Microbial Pathogenesis 8, 91--99.

Smith, H. R.. Willshaw, G. A. \& Rowe, B. (1982). Mapping of a plasmid coding for colonization factor antigen 1 and heat-stable enterotoxin production isolated from an enterotoxigenic strain of Escherichia coli. Journal of Bacteriology 149, 264-275.

SMith, H. R, Scotland, S. M. \& Rowe, B. (1985). Genetics of E. coli virulence. In The Virulence of Escherichia coli, Society for General Microbiology Special Publication no. 13, pp. 227-269. Edited by M Sussman. London: Academic Press.

SMYTH, C. J. (1982). Two mannose-resistant haemagglutinins on enterotoxigenic Escherichia coli of serotype O6:K $15: \mathrm{H} 16$ or $\mathbf{H}^{-}$ isolated from travellers' and infantile diarrhoea. Journal of General Microbiology 128, 2081-2096.

SOUTHERN, E. M. (1975). Detection of specific sequences among DNA fragments separated by gel electrophoresis. Journal of Molecular Biology 98, 503-517.

Tacket, C. O., Maneval, D. R. \& Levine, M. M. (1987). Purification, morphology, and genetics of a new fimbrial putative colonization factor of enterotoxigenic Escherichia coli O159:H4. Infection and Immunity 55, 1063-1069.

Thomas, L. V., McConneli, M. M ., Rowe, B. \& Field, A. M. (1985) The possession of three novel coli surface antigens by enterotoxigenic Escherichia coli strains positive for the putative colonization factor PCF8775. Journal of General Microbiology 131, 2319-2326.

Thomas, L. V., Rowe, B. \& MCCONNELL, M. M. (1987). In strains of Escherichia coli $\mathrm{O} 167$ a single plasmid encodes for the coli surface antigens CS5 and CS6 of putative colonization factor PCF8775, heat-stable enterotoxin and colicin la. Infection and Immunity 55, 1929-1931.

Thorne, G. M., Deneke, C. F. \& Gorbach, S. L. (1979) Haemagglutination and adhesiveness of toxigenic Escherichia coli isolated from humans. Infection and Immunity 23, 690-699.

Towbin, H., Staehelin, T. \& Gordon, J. (1979). Electrophoretic transfer of proteins from polyacrylamide gels to nitrocellulose sheets procedure and some applications. Proceedings of the National Academy of Sciences of the United States of America 76, 43504354

Willshaw, G. A., SMith, H. R. \& ANDerson, E. S. (1979). Application of agarose gel electrophoresis to the characterization of plasmid DNA in drug-resistant enterobacteria. Journal of General Microbiology 114, 15-25.

Willshaw, G. A., Smith, H. R. \& Rowe, B. (1983). Cloning of regions encoding colonization factor antigen $\mathbf{I}$ and heat-stable enterotoxin in Escherichia coli. FEMS Microbiology Letters 16, 101-106.

Willshaw, G. A, Smith, H. R., McConnell, M. M. \& Rowe, B. (1985). Expression of cloned plasmid regions encoding colonization factor antigen 1 (CFA/I) in Escherichia coli. Plasmid 13, 8-16.

Willshaw, G. A., McConnell, M. M., Smith, H. R. \& Rowe, B $(1990 a)$. Structural and regulatory genes for coli surface associated antigen 4 (CS4) are encoded by separate plasmids in enterotoxigenic Escherichia coli strains of serotype O25:H42. FEMS Microbiology Letters 68, 225-260

Willshaw, G. A, Smith, H. R., McConnell, M. M., Gaastra, W., Thomas, A., Hibrerd, M. \& Rowe, B. (1990 b). Plasmid-encoded production of coli surface-associated antigen $1(\mathrm{CS} 1)$ in a strain of Escherichia coli serotype O139:H28. Microbial Pathogenesis 9, 1-11. 